\title{
Global Competitiveness Indicators as a Determinant of Brownfield Investments in Serbia: Generalized Linear Model
}

\author{
Safet Kurtovic ${ }^{1}$, Sead Talovic ${ }^{2} \&$ Lejla Dacic $^{3}$ \\ ${ }^{1}$ Faculty of Economics, Dzemal Bijedic University of Mostar, B\&H \\ ${ }^{2}$ Ministry of Foreign Trade and Economic Relations of Bosnia and Herzegovina, B\&H \\ ${ }^{3}$ Faculty of Management and Business Economics, University of Travnik, B\&H \\ Correspondence: Safet Kurtovic, Faculty of Economics, Dzemal Bijedic University of Mostar, Mithada Hujdura \\ Hujke bb, 88 000, Mostar, B\&H.
}

Received: July 7, 2015

doi:10.5430/rwe.v6n3p1
Accepted: August 1, 2015

Online Published: August 24, 2015

\begin{abstract}
This paper studies the effect of global competitiveness indicators on attracting brownfield investment (BI) in Serbia. It analyzes cross-section data in the time period from 2007 to 2013. It applies the econometrical technique called Generalized Linear Model and measures the effect of global competitiveness indicators on attracting foreign investment in brownfield sites in Serbia. Our research has shown that global competitiveness indicators such as Gross domestic product, Quality of overall infrastructure, Effect of taxation on incentives to invest, Availability and quality of information and Legislation are statistically significant.
\end{abstract}

Keywords: Brownfield investment, competitiveness, global indicators, transition

\section{Introduction}

Competitiveness implies creating conditions under which companies and individuals are more productive and achieve greater profit and higher rates of return on investment that reflect the living standard of a given country (Porter, 2007). In 2004, Sala-I-Martin created Global Competitiveness Index (GCI), which envelops macroeconomic and microeconomic competitiveness factors (Sala-i-Martin, X., et al., 2008). At the micro level, competitiveness is the ability of companies to compete, grow and be profitable (Martin, n.d.), or the ability of a company to produce and sell products and services at a lower price compared to its competitors (Vukovic, 2013). Competitiveness at the macroeconomic level is associated with strenthening productivity at the national level leading to rising living standards, expanding employment opportunities, and the ability of a nation to maintain its international obligations (Martin, n.d.).

Global Competitiveness Index (GCI) encompasses nine factors strongly affecting the productivity and competitiveness of a given country. Competitiveness of a country is determined by a set of factors such as Institutions, Infrastructure, Macroeconomy, Health and primary education, Higher education and training, Market efficiency, Technological readiness and Business sophistication and innovation affecting the productivity of the country. According to the GCI, countries are divided into three groups: factor-driven, efficiency-driven, and innovation-driven (Lopez-Carlos, A., et al., 2006).

During the turbulent 1990's, Serbia inherited great economic and social problems. Following democratic reforms in 2000, Serbia attempted to perform certain economic reforms and join the transition countries that were in the phase between factor-driven and efficiency-driven. On its way to transition reforms, Serbia faced numerous economic and social challenges. According to the Global Competitiveness Index, Serbia achieved a very modest result i.e. ranked very low on the national economies' global competitiveness ladder as compared to the neighbouring countries. Thus, during the period 2007-2008 and 2008-2009, Serbia occupied 91th and 84th place in the world, respectively (Sala-i-Martin, X., et al., 2008). After that, Serbia regressed during 2011-2012 and 2012-2013 ending up in 95th place, while in 2014-2015 it ranked 94th in the world according to the GCI. In terms of ranked areas such as Basic requirements, Serbia occupies $101^{\text {st }}$ place in the world, while the best ranked categories are Health and primary education and Infrastructure occupying $68^{\text {th }}$ and $77^{\text {th }}$ place respectively. With respect to Efficiency enhancers, among the best ranked are Technological readiness, Market size and Higher education and training i.e. $49^{\text {th }}, 71^{\text {st }}$ and $74^{\text {th }}$ in 
the world (Sala-i-Martin, X. et al., 2014). Based on global competitiveness index, it can be concluded that Serbia belongs to the group of countries with low competitiveness intensity; however, it achieved certain progress in the abovementioned areas, which makes it competitive in the process of foreign direct investment or brownfield investment inflow.

Due to the slow company privatization process and delay in the adoption of the Bankruptcy Law, some of the state-owned companies in Serbia became brownfield sites. Regeneration of brownfield sites in Serbia requires both vertical and horizontal approach. Vertical approach encompasses three aspects: state, regional and local level. At the state level, implementation is performed through regulation of internal strategy and national legislation. At the regional level, instruments and measures that will attract foreign investors are being implemented. Finally, at the local level, attraction of brownfield investments can be stimulated through urban planning and various fiscal measures and policies related to land. Horizontal approach pertains to the activities and cooperation with partners on the local community development (Dulic, 2005).

Brownfield sites revitalization in Serbia is at a very low level. One of the reasons for such a state is the rather late adoption of the brownfield definition. Brownfield site is defined in Serbia as the "(...) land which was previously built and used, but in the meantime, due to financial or other economic reasons became abandoned" (Peric and Furundzic, 2014). In the European context there are a number of definitions and interpretations, with the most common one suggested by the working group CLARINET (Contaminated Land Rehabilitation Network for Environmental Technologies), which states: "The brownfield are sites that had previously been under the influence of their users and the surrounding areas, which are neglected or underutilized, which may have potential problems with lack of maintenance, which are located mainly in developed urban areas and require intervention to bring them back to beneficial use and may have real or perceived contamination problems" (CABERNET, 2006; Oliver, et al., 2010).

In 2014, there were 449 brownfield sites registered in Serbia (Serbia Investment and Export Promotion Agency, 2015). In the period from 2002 to 2012, total inflow of brownfield investments amounted to 3.773 billion euros. 2003 was the record year with the inflow of brownfield investments of 1.577 billion euros. After the record inflow achieved in 2003, there are 2005 and 2009 standing out with brownfield investments in the amount of 605 and 978 million euros, respectively. From 2000 to 2014, Serbia achieved the inflow of FDI in the amount of 21 billion euros. Based on the World Investment Report of 2012, 50\% greenfield investments in the SEE region pertained to Serbia. Brownfield investments during 2012 and 2013 were dominantly made in the energy sector $48 \%$, production sector $20 \%$ and trade $7 \%$ (Invest in Serbia, 2013).

This paper's subject is the analysis of the impact of global competitiveness indicators on the current state and potential for brownfield investment inflow in Serbia. Brownfield investment inflow in Serbia has been steadily increasing over the last ten years. However, it is evident that the amount of brownfield investment is unsatisfactory and that it could be greater having in mind the current brownfield site potential. Brownfield investment inflow is affected by global competitiveness indicators such as Gross domestic product, Quality of overall infrastructure, Effect of taxation on incentives to invest, Availability and quality of information, Legislation, etc. In order to attract the greatest possible amount of brownfield investment, Serbia is attempting to carry out certain reforms aimed at achieving positive global competitiveness indicators and thus attract significant investments. To that effect, this paper aims to meet the following set objectives: study the effect of gross domestic production on brownfield investment inflow; study the effect of quality of overall infrastructure on brownfield investment inflow; study the effect of taxation on incentives to invest; study the effect of legislation and availability and quality of information on brownfield investment inflow in Serbia.

This paper sets up the null and alternative research hypothesis proven through the application of the generalized linear model.

Hypothesis $H_{0}$ : Global competitiveness indicators do not affect the brownfield investment inflow in Serbia or $\mathrm{H}_{0}: \beta_{1}=1$.

Hypothesis $H_{1}$ : Global competitiveness indicators affect the brownfield investment inflow in Serbia or $\mathrm{H}_{1}: \beta_{1} \neq 1$.

The paper consists of sections as follows: the introductory section provides the subject, research objectives and research hypotheses; Section 2 provides an overview of literature or research closely related to this paper's research subject; Section 3 describes econometric techniques and databases used in the research; Section 4 provides the empirical results of the research and, finally, Section 5 contains the Conclusion. 


\section{Literature Review}

Jackson and Grab (2002) analyzed the factors affecting economic profitability of brownfield investments and availability of information pertaining to brownfield sites in urban areas of the Central and Southeast Europe. Apart from this, they researched the main barriers affecting the reuse of brownfield sites. In order to overcome the mentioned barriers, they proposed application of a consistent methodology that would bring benefits to the local community. Jankovych (2005) studied the factors based on which a mechanism is created for the classification of brownfield sites for reuse. Experiences of Germany and France could serve as a possible solution for the Central and Eastern European countries. Groenendijk (2006) researched all possible benefits and costs of brownfield revitalization and proposed four models for it. Ganser and Williams (2007) studied the issue of quantification of objectives for the development of brownfields at the national level and pointed out the significance of regeneration of urban brownfield sites and the reduction in use of greenfield sites. Paull (2008) quantified the effect of brownfield reuse on the environment and social community. In the economic sense, brownfield reuse helps create new jobs, encourages investments and enhances the environment. Priručnik za donosioce odluka i profesionalce (2008) provided an overview of the state and perspectives of brownfields in Serbia. This study described the possible solutions for the issue of brownfield sites in Serbia. Chilton et al., (2008) studied the impact of brownfield revitalization in Charlotte, USA on the social, economic and natural environment. Estrin and Meyer (2010) studied the importance of brownfield acquisition as a way of searching for innovative resources on the fast-growing markets. They concluded that many companies that were purchased in the growing markets went through a certain level of reorganization, while simultaneously retaining the key competencies. Lucka (2010) studied the issue of revitalization of brownfield sites in industrial areas with reduced economic relevance that is, therefore, considered a possible important generator of new investments and jobs.

In his research, Tang (2011) developed a framework for defining brownfield sites and analyzed qualitative and quantitative data pertaining to the land use and sustainability. Using England and Taiwan as examples, he concluded that their brownfield revitalization policies differed depending on the population density and the level of economic development. The Deliverable Report (2012) paid particular attention to the issue of a lack of database on brownfield sites. Frantal et al., (2013) studied the impact of factors on the successful regeneration of brownfield sites. Using the case of South Moravia they analyzed the spatial and functional distribution of brownfield sites. Frank (2014) carried out a research on economic and fiscal benefits, availability of information on brownfields, etc. Based on several case studies on American cities, he determined advantages and disadvantages of brownfields. Frantal et al., (2015) performed a comparative study on interest groups from the Czech Republic, Germany, Romania and Poland. They found that, apart from the total costs, the process of regeneration of contaminated land was also affected by the ownership issues, local self-government, legislation, location and communications.

\section{The Econometric Model and Data}

Our economic analysis is based on the aplication of the generalized linear model. We have used cross-section data for the period from 2007 to 2013. Our decision to choose this data series stems from the fact that until 2006, Serbia had been in union with Montenegro, constituting the Federal Republic of Yugoslavia. In 2006, Serbia became an independent state. The data has been acquired from the National Bank of Serbia, Serbia Investment and Export Promotion Agency, www.naled-serbia.org/search, The Global Competitiveness Report 2006-2015.

Applying the generalized linear model, we have measured the impact of Global Competitiveness Indicators on the inflow of brownfield investment in Serbia. Within the quantitative approach, we have determined brownfield investment as the dependent variable, while the independent variables are Gross domestic product, Quality of overall infrastructure, Effect of taxation on incentives to invest, Availability and quality of information and legislation. We selected these variables in accordance with the relevance of their impact on the explanation of relation between global competitiveness indicators and brownfield investment inflow. Our empirical analysis comprises several steps. First, we introduced the generalized linear model equation. Second, we provided a theoretical explanation of the generalized linear model. Third, we demonstrated the correlation between independent variables. Fourth, we applied the generalized linear model and measured the effect of independent variables on the dependent variable.

Within our research we used the gravity model equation and our empirical specification of the generalized linear model was as follows:

$$
\log \text { Browi }=\beta_{0}+\beta_{1} \log G D P+\beta_{2} \log Q \text { oing }+\beta_{3} \log E t i i+\beta_{4} A q i+\beta_{5} \operatorname{Leg}+, \ldots,+\varepsilon
$$

where:

Browi - variable Brownfield investments, 
$G D P$ - variable Gross domestic product,

Qoing - quality of overall infrastructure,

Etii - effect of taxation on incentives to invest,

$A q i$ - dummy variable Availability and quality of information,

Leg - dummy variable Legislation,

$\varepsilon$ - residual or error.

Brownfield investments mostly occur in the form of acquisitions. These investments are essential to the revitalization and economic enhancement of derelict and abandoned sites. Gross domestic product represents a very important macroeconomic indicator showing the value of final goods and services produced in the country within a calendar year, expressed nominally. Its increase or reduction is a powerful indicator considered by the investors when deciding upon site selection. Indicator Quality of overall infrastructure pertains to the quality of road and railway infrastructure, quality of port infrastructure, quality of air transport infrastructure, quality of electricity supply, airplane seats availability, number of mobile and fixed line telephone subscribers. Indicator Effect of taxation on incentives to invest is an important indicator that can have a stimulative or destimulative effect on attracting investments. Tax reliefs include direct and indirect tax incentives. Dummy variable Availability and quality of information pertains to information regarding brownfield sites, techniques and best practices. Finally, dummy variable Legislation pertains to the legal framework regulating brownfield sites, eligible forms of investment, protection of foreign property and the like.

Generalized linear models (GLMs) are a large class of statistical models for relating responses to linear combinations of predictor variables, including many commonly encountered types of dependent variables and error structures as special cases. In addition to regression models for continuous dependent variables, models for rates and proportions, binary, ordinal and multinomial variables and counts can be handled as GLMs. The GLM approach is attractive because it (1) provides a general theoretical framework for many commonly encountered statistical models; (2) simplifies the implementation of these different models in statistical software, since essentially the same algorithm can be used for estimation, inference and assessing model adequacy for all GLMs (Jackman, 2014).

The generalized linear model is a generalization of the traditional linear model. It differs from a linear model in that it assumes that the response distribution is related to the linear predictor through a function called the link function.

Let $y_{1}, \ldots, y_{n}$ denote $n$ independent observations on a response. We treat $y_{i}$ as a realization of a random variable $Y_{i}$. In the general linear model we assume that $Y_{i}$ has a normal distribution with mean $\mu_{i}$ i variance $\sigma^{2}$

$$
Y_{i} \sim N\left(\mu_{i}, \mu^{2}\right)
$$

and we further assume that the expected value $\mu_{i}$ is a linear function of $p$ predictors that take values $X_{i}^{\prime}=$ $\left(x_{i 1}, \ldots, x_{i p}\right)$ for the $i-t h$ case, to that

$$
\mu_{i}=x_{i}^{\prime} \beta
$$

where $\beta$ is a vector of unknown parameters. We will generalize this in two steps, dealing with the stochastic and systematic components of the model. The response $y$ is assumed to have a distribution from the exponential family (for example, normal, gamma, Poisson, binomial, etc.). The vector $\eta_{0}$ is called an offset variable. As in least squares regression, $\mathrm{X}$ is the design matrix and $\beta$ is a vector of unknown parameters.

Poisson regression is very similar to logistic regression. It can be viewed as the limiting case as the proportion becomes smaller but the denominator becomes larger. True Poisson processes are rare, but Poisson models can still be fit to a variety of data. For the random component, one assumes Poisson errors. Often 'counting' type processes have a Poisson distribution. For the systematic component, one can use a mixture of categorical or continuous variables. They must have a linear relationship to each other (as discussed earlier), but that is true of all linear predictors (LP). The normal link function is the natural logarithm. Thus, in Poisson regression, we relate the logarithm of the observed counts to the linear predictor. The predicted counts are permitted to have a Poisson distributed error distribution to allow for discrepancies between the observed counts and those predicted by the model. One difference between the Poisson regression models and the other GLMs is that there can be independent variables in the LP which have a known $\beta$. These are often referred to as the offset in a Poisson regression. The offset constitutes the denominator of a rate, but has to be log-transformed before it is included in the LP (Yuen, 2001).

Poisson regression is used when the dependent variable is a count. Procedure calculates power and sample size for testing the hypothesis that $\beta_{1}=0$ versus the alternative that $\beta_{1}=B$. Note that $e^{\beta^{1}}$ is the change in the rate for a 
one-unite change in $X_{1}$ when the rest of the covariates are held constant. The procedure assumes that this hypothesis will be tested using the score statistic

$$
z=\frac{\widehat{\beta}_{1}}{\sqrt{\operatorname{Var}\left(\widehat{\beta}_{1}\right)}}
$$

Let us denote the outcome variable by $y_{i}$, taking values $0,1,2 \ldots$. Our goal is to explain the distribution of $y_{i}$, or the expected value of $y_{i}$, given a set of characteristics $x_{i}$. Let us assume that the expected value of $y_{i}$, given $x_{i}$, is given by (Verbeek, 2004)

$$
E\left\{y_{i} / x_{i}\right\}=\exp \left\{x_{i}^{\prime} \beta\right\}
$$

where $\beta$ is a set of unknown parameters. Because $y_{i}$ is non-negative, we choose a functional form that produces non-negative conditional expectations. The above assumption relates the expected outcome of $y_{i}$ to the individual characteristics in $x_{i}$, but does not fully describe the distribution. If we want to determine the probability of a given outcome e. $g . P\left\{y_{i}=1 / x_{i}\right\}$, additional assumptions are necessary.

A common assumption in count data models is that, for given $x_{i}$, the count variable $y_{i}$ has a Poisson distribution with expectation that the mean and the variance are equal

$$
\lambda_{i} \equiv \exp \left\{x_{i}^{\prime} \beta\right\}
$$

This implies that the probability as function of $y_{i}$ conditional upon $x_{i}$ is given by

$$
\operatorname{Pr}\left\{y_{i}=y / x_{i}\right\}=\frac{\exp \left\{-\lambda_{i}\right\} \lambda_{i}^{y}}{y !}, y=0,1,2, \ldots, 7.42
$$

where $y$ ! is short hand notation for $y x(y-1) x \ldots x 2 x 1 y$ (referred to as ' $y$ factorial'), with 0 ! $=1$. Substituting the appropriate functional form for $\lambda_{i}$ produces expressions for the probabilities that can be used to construct the $\log$-likelihood function for this model, referred to as the Poisson regression model. Assuming that observations on different individuals are mutually independent, estimation of $\beta$ by means of maximum likelihood is therefore reasonably simple: the log-likelihood function is the sum of the appropriate log probabilities, interpreted as a function of $\beta$. If the Poisson distribution is correct, and assuming we have a random sample of $y_{i}$ and $x_{i}$, this produces a consistent, asymptotically efficient and asymptotically normal estimator.

An important drawback of the Poisson distribution is that it automatically implies that the conditional variance of $y_{i}$ is also equal to $\lambda_{i}$. That is, in addition to (5), the assumption in (7) implies that

$$
V\left\{y_{i} / x_{i}\right\}=\exp \left\{x_{i}^{\prime} \beta\right\}
$$

This condition is referred to as equidispersion and illustrates the restrictive nature of the Poisson distribution. In many applications, the equality of the conditional mean and variance of the distribution has been rejected (Verbeek, 2004). With mean and the variance are equal

$$
E\left(Y_{i}\right)=\operatorname{Var}\left(Y_{i}\right)=\lambda_{i}
$$

where $\lambda_{i} \equiv \exp \left\{X_{i}^{\prime} \beta\right\}, \quad X_{i}$ is the $i^{\text {th }}$ row of covariate matrix, and $\beta=\left(\beta_{1}, \beta_{2}, \ldots, \beta_{x}\right)$ are unknown K-dimensional vector of regression parameters. The mean of $Y_{i}$ is given by $E\left(\frac{Y_{i}}{X_{i}}\right)$ and the variances of $Y_{i}$ is given by $\left(\frac{Y_{i}}{X_{i}}\right)$. The parameters $\beta$ can be estimated by Maximum likelihood estimated method

$$
L(\beta)=\prod_{i=1}^{n} \frac{\exp \left(-\lambda_{i}\right) \lambda_{i}^{y^{i}}}{y_{i} !}
$$

The $\log$ - likelihood function is given by:

$$
\operatorname{LnL}(\beta)=\sum_{i=1}^{n}\left[-\lambda_{i}+y_{i} \ln \lambda_{i}-\ln y_{i !}\right]=\sum_{i=1}^{n}\left[y_{i}\left(X_{i}^{\prime} \beta\right)-\exp \left(X_{i}^{\prime} \beta\right)-\ln y_{i} !\right]
$$

By differentiating equation (4) with respect $\beta$

$$
\frac{\partial \ln L(\beta)}{\partial \beta_{j}}=\sum_{i=1}^{n}\left(y_{i}-\exp \left(X_{i}^{\prime} \beta\right) X_{i}\right)=0, j=1,2 \ldots k
$$


Yields K nonlinear equations and solve these equations by Newton-Raphson method or by iteratively weighted least square procedure the parameters are estimated (Rashwan and Kamel, 2011).

In Poisson regression, we supose that the Poisson incidence rate $\mu$ is determined by a set of $k$ regressor variables $\left(\right.$ the $\left.X_{s}^{\prime}\right)$. The expression relating these quantities is

$$
\mu=\exp \left(\beta_{0}+\beta_{1} X_{1}+\beta_{2} X_{2}+, \ldots,+\beta_{k} X_{k}\right)
$$

The regression coefficients $\beta_{0}, \beta_{1}, \beta_{2}, \ldots, \beta_{k}$ are unknown parameters that are estimated from a set of data. Their estimates are labeled $b_{o}, b_{1}, \ldots, b_{k}$.

Using this notation, the fundamental Poisson regression model for an observation $i$ is written as

$$
\operatorname{Pr}\left(Y_{i}=\frac{y_{i}}{\mu_{i}}, t_{i}\right)=\frac{e^{-\mu_{i} t_{i}\left(\mu_{i} t_{i}\right) y_{i}}}{y_{i} !}
$$

Where

$$
\begin{gathered}
\mu_{i}=\lambda\left(x_{i}^{\prime} \beta\right) \\
\lambda\left(x_{i}^{\prime} \beta\right)=\exp \left(\beta_{0}+\beta_{1} X_{1 i}+\beta_{2} X_{2 i}+, \ldots,+\beta_{k} X_{k i}\right)
\end{gathered}
$$

This is, for a given set of values of the regressor variables, the outcome follows the Poission distribution (NCSS Statistical Software, n.d.).

\section{Estimation Results}

Having analyzed the correlation between independent variables, we determined that there is a slightly increased correlation between Quality of overall infrastructure (Qoinf) and Legislation (Leg) i.e. $p$-value is $0.856560 \%$, and also between Quality of overall infrastructure (Qoinf) and Availability and quality of information (Aqi), where $p$-value is $0.868810 \%$. A negative and moderate correlation between independent variables has been noted in other cases (Table 1). Finally, we concluded that our model does not have a problem with multicollinearity.

Table 1. Correlation between independent variables

\begin{tabular}{cccccc}
\hline & GDP & QOINF & LEG & AQI & ETII \\
\hline GDP & 1.000000 & -0.502655 & -0.532565 & -0.506332 & 0.031635 \\
\hline QOINF & -0.502655 & 1.000000 & 0.856560 & 0.868810 & 0.255470 \\
\hline LEG & -0.532565 & 0.856560 & 1.000000 & 0.730297 & 0.580381 \\
\hline AQI & -0.506332 & 0.868810 & 0.730297 & 1.000000 & 0.099340 \\
\hline ETII & 0.031635 & 0.255470 & 0.580381 & 0.099340 & 1.000000 \\
\hline
\end{tabular}

Note: $* * * 0.01, * * 0.05$ and $* 0.10$ represent statistical significance at the $1 \%, 5 \%$, and $10 \%$ level, respectively.

Source: Author's

Through the application of the generalized linear model, we concluded that all global competitiveness indicators are statistically significant i.e. positively affect the inflow of brownfield investment in Serbia (see Table 2). In an attempt to determine the impact of global competitiveness indicators on brownfield investment inflow in Serbia, we have observed the individual effect of independent variables on the dependent variable. Thus, Gross domestic product $(G D P)$ has a $p$-value of $0.0000 \%$ that is statistically significant or lower than the determined value of $0.05 \%$; therefore, we reject the $H_{0}$ hypothesis and accept the alternative $H_{1}$ hypothesis. GDP in Serbia has cumulatively increased in the observed period $2007-2013$, which positively affected the inflow of brownfield investment. In 2008 GDP was 50 billion dollars, while in 2012 it decreased to 37 billion dollars. However, during 2013, GDP increased to 43 billion dollars. A mild increase is expected in the following period, which should lead to further increase in brownfield investment inflow in Serbia.

Indicator Quality of overall infrastructure (QOINF) has a $p$-value of $0.0393 \%$, which renders it significant or lower than the determined value of $0.05 \%$; hence, we reject the $H_{0}$ hypothesis and accept the alternative $H_{1}$ hypothesis. This indicator (QOINF) comprises the quality of road and railway infrastructure, quality of port infrastructure, quality of air transport infrastructure, quality of electricity supply, airplane seats availability, number of mobile and fixed line telephone subscribers. In the observed time period, Serbia achieved certain progress in terms 
of improving both overall and individual infrastructure. The greatest progress was made in improving the quality of air transport infrastructure, quality of electricity supply and number of mobile and fixed line telephone subscribers. On the other hand, no significant progress was made in regard to the quality of road and railway transport, which, in fact, represent Serbia's weakest infrastructural components.

Table 2. Impact of global competitiveness indicators on brownfield investment inflow in Serbia

\begin{tabular}{ccrrr}
\hline Method: Generalized Linear Model (Quadratic Hill Climbing) & & & \\
\hline Variable & Coefficient & Std. Error & z-Statistic & Prob. \\
\hline GDP & -0.118682 & 0.018833 & -6.301752 & 0.0000 \\
\hline QOINF & 0.986672 & 0.478773 & 2.060836 & 0.0393 \\
\hline AQI & 0.341105 & 0.167585 & 2.035410 & 0.0418 \\
\hline ETII & 7.101452 & 0.855201 & 8.303838 & 0.0000 \\
\hline C & -10.01362 & 2.608064 & -3.839483 & 0.0000 \\
\hline & Mean dependent var & 568.1143 & S.D. dependent var & 252.4323 \\
\cline { 2 - 5 } & Sum squared resid & 161100.8 & Quasi-log likelihood & 21588.99 \\
\cline { 2 - 5 } & Restr. quasi-logl & 21245.35 & Quasi-LR statistic & 687.2858 \\
\cline { 2 - 5 } & Prob(Quasi-LR stat) & 0.000000 & Pearson SSR & 419.5462 \\
\cline { 2 - 5 } & Pearson statistic & 419.5462 & Dispersion & 1.000000 \\
\hline
\end{tabular}

Note: $* * * 0.01, * * 0.05$, and $* 0.10$ represent statistical significance at the $1 \%, 5 \%$, and $10 \%$ level, respectively.

Source: Author's

Effect of taxation on incentives to invest (ETII) has a $p$-value of $0.0000 \%$ that is statistically significant or lower than the determined value of $0.05 \%$; therefore, we reject the $H_{0}$ hypothesis and accept the alternative $H_{1}$ hypothesis. Indicator Effect of taxation on incentives to invest (ETII) pertains to granting direct or indirect tax reliefs in order to encourage inflow of investments. Serbia prefers granting direct tax incentives such as subsidies to foreign investors per each newly created job. Additionaly, through its stimulative tax policy with respect to income tax and other taxes, Serbia attempts to become the most favourable investment location in the Western Balkans. To that effect, it has made significant progress.

Dummy indicator Availability and quality of information has a $p$-value of $0.0418 \%$ that is significant or lower than the determined value $0.05 \%$; therefore, we reject the $H_{0}$ hypothesis and accept the alternative $H_{1}$ hypothesis. Availability and quality of information pertains to availability of information on brownfield sites in Serbia in one place. The official website of the Investment and Export Promotion Agency of the Republic of Serbia offers a unified database on all forms of foreign investments in Serbia, including investments in brownfield sites. In addition to this, significant progress has been made with respect to informing the public about successful brownfield investment cases. However, the downside is the insufficient information on the implementation of certain policies and procedures regularly adopted at the local or regional level.

Finally, dummy indicator Legislation has a $p$-value of $0.0000 \%$ that is significant or lower than the determined value $0.05 \%$; therefore, we reject the $H_{0}$ hypothesis and accept the alternative $H_{1}$ hypothesis. Over the past several years, more precisely since 2006, Serbia has adopted a number of important laws pertaining to protection of foreign property, foreign investors, etc. In addition, Serbia adopted The Law on Spatial Planning 2010-2020, which regulates brownfield sites related issues and emphasizes the importance of brownfield regeneration as a tool for a better utilization of the territorial capital of Serbia. However, this law created an anomaly with respect to preparing investment plans. Namely, large new areas of land have been reserved without any requirements regarding the existing industrial land. Thus, new factories will be located in greenfields (greenfield investments), instead of encouraging the investors to revitalize and reuse the existing industrial facilities and locations.

\section{Conclusion}

Foreign investment inflow is closely related to global competitiveness indicators. Over the last two decades, Serbia has achieved modest progress in the area of enhancing the competitiveness of the national economy. To that effect, it initiated certain reforms in order to improve basic requirements, efficiency enhancers, innovation and sophistication 
factors. However, not all the reforms have been successfully carried out. In fact, most of them have not even gone further than the starting point. The reform that achieved the greatest progress was improving basic requirements and efficiency enhancers. Positive results have been achieved in the field of reforming basic requirements, i.e. in the field of improving the overall infrastructure, availability of information on investment sites and legislation. In terms of infrastructure, the best results have been achieved in the field of improving the quality of fixed telephone service, quality of electricity supply and quality of roads. Regarding legislation, Serbia adopted several laws protecting foreign property, foreign investors, as well as the Law on Spatial Planning and the like. The disadvantage of the legislation reform is the presence of a high degree of corruption, disrespect for intellectual property, time consuming economic court proceedings, etc. Availability of information on investment sites has achieved significant progress over the last few years. Official websites of state institutions contain information regarding investment conditions and potential brownfield sites, which greatly facilitates and improves the foreign investment process. The best results by far have been achieved in the field of enhancing the economic efficiency of the market, after Serbia had carried out certain fiscal policy reforms aimed at reducing numerous direct and indirect taxes and simplified the procedures for doing business, issuing permits, etc. However, this is far from the desired goal, which means that numerous economic reforms await Serbia on its way to improve its competitiveness at the global level. In accordance with the enhancement of the global competitiveness index of the economy of Serbia, there has been a noticeable increase in the brownfield investment inflow.

Having applied the Generalized Linear Model, this research paper studied the effect of global competitiveness indicators on attracting investments in brownfield sites in Serbia. The research has shown that global competitiveness indicators such as Gross domestic product, Quality of overall infrastructure, Effect of taxation on incentives to invest, Availability and quality of information and Legislation are statistically significant i.e. positively affect the inflow of foreign investment in brownfield sites in Serbia.

This research paper can serve as a starting point for future research on the effect of competitiveness indicators in the areas such as Institutions, Macroeconomic environment, Health and primary education, Higher education and training, Goods market efficiency and the like on attracting brownfield investment in Serbia or Western Balkan countries.

\section{References}

CABERNET. (2006). Sustainable Brownfield Regeneration, CABERNET Network Report, University of Nottingham, 3-138. Retrieved from http://www.cabernet.org.uk/resourcefs/427.pdf

Chilton, K., Schwarz, P., \& Godwin, K. (2009). Verifying the Social, Environmental, and Economic Promise of Brownfield Programs, Brownfields Training Research and Technical assistant Grants and Cooperative Agreements Program - BFRES-04-02, 1-44. Retrieved from http://www.epa.gov/brownfields/trta_k6/trta_report_2009.pdf

Deliverable Report. (2012). Brownfield redevelopment as an alternative to greenfield consumption in urban development in Central Europe, In Siebielec, G. (Ed), Urban SMS Soil Management Strategy, PP8 - Institute of Soil Science and Plant Cultivation - State Research Institute, January, 1-25. Retrieved from http://www.umweltbundesamt.at/fileadmin/inhalte/urbansms/pdf_files/final_results/19_Brownfields_report_613 final.pdf

Dulic, O. (2013). Problem of Brownfield Sites in Serbia, 1-7. Retrieved from http://academia-danubiana.net/wp-content/uploads/2013/08/Olivera-Duli\%C4\%87-Problem-of-brownfield-sites -in-Serbia.pdf

Estrin, S., \& Meyer, E. K. (2010). Brownfield Acquisitions: A Reconceptualization and Extension, Working Paper, September. Retrieved from http://www.klausmeyer.co.uk/publications/WIP_Estrin_Meyer_Brownfield_2009.pdf

Frank, N. (2014). Benefits of Public Investment in Brownfield Cleanup and Redevelopment, August, 1-19. Retrieved from http://www.wisconsinplanners.org/attachments/Jobs/proposals/Brownfields_Funding_lit_review_August_2014. pdf

Frantal, B., Kunc, J., Novakova, E., Klusacek, P., Martinat, S., \& Osman, R. (2013). Location matters! Exploring brownfields regeneration in a spatial context (a case study of the South Moravian Region, Czech Republic), Moravian Geographical Reports, 21(2), 5-19. http://dx.doi.org/10.2478/mgr-2013-0007 
Frantal, B., Kunci, J., Klusacek, P., \& Martinat, S. (2015). Assessing Success Factors of Brownfields Regeneration: International and Inter-Stakeholder Perspective, Transylvanian Review of Administrative Sciences, (44), 92-107. Retrieved from http://rtsa.ro/tras/index.php/tras/article/view/427/417

Ganser, R., \& Williams, K. (2007). Brownfield Development: Are We Using the Right Targets? Evidence from England and Germany, European Planning Studies, 15(5), 604-620. http://dx.doi.org/10.1080/09654310600852654

Groenendijk, N. (2006). Financing Techniques for Brownfield Regeneration - A practical guide, Revitalising industrial sites. Dept. of Legal \& Economic Governance Studies, Centre for European Studies, University of Twente Netherlands, June, 3-27. from http://doc.utwente.nl/77386/2/Groenendijk06financing_techniques.pdf

Invest in Serbia. (2013). Invest in Serbia, NDP Audit and Cosulting, Belgrade, 1-16. Retrieved from $\mathrm{http}: / / w w w . i n v e s t i n s e r b i a . b i z /$ file/publications/Invest_In_Serbia.pdf

Jackson, J., \& Grab, Y. (2002). Facilitating brownfield redevelopment in Central Europe: Overview and proposals, Institute for Transport and Development Policy, 2-17. Retrieved from http://www.prague2003.fsu.edu/content/pdf/271.pdf

Jackman, S. (2014). Generalized Linear Models, Stanford University, 1-7. Retrieved from http://jackman.stanford.edu/papers/glm.pdf

Jankových, V. (2005). Brownfields classification, AESOP, Vienna, 1-7. Retrieved from http://aesop2005.scix.net/data/papers/att/185.fullTextPrint.pdf

Lopez-Carlos, A., Altinger, L., Blanke, J., Drzeniek, M., \& Mia I. (2006). The Global Competitiveness Index: Identifying the Key Elements of Sustainable Growth. In Schwab, K., \& Porter, M. (Eds), The Global Competitiveness Report 2006-2007, World Economic Forum, Geneva, Switzerland, 10. Retrieved from http://www3.weforum.org/docs/WEF_GlobalCompetitivenessReport_2006-07.pdf

Lucka, L. (2010). New perspective of the regional development of old industrial areas, XXII Congress of the Czech Geographical Society, 31. srpna - 3. záŕí Ostrava, 566-570. Retrieved from http://konference.osu.cz/cgsostrava2010/dok/Sbornik_CGS/Modely_a_strategie_reg_rozvoje/New_perspective_ of the_regional_development.pdf

Martin, L. R. (n.d.). A Study on the Factors of Regional Competitiveness, A draft final report for The European Commission Directorate-General Regional Policy, 1-8. Retrieved from http://ec.europa.eu/regional_policy/sources/docgener/studies/pdf/3cr/competitiveness.pdf

NCSS Statistical Software. (n.d.). Regression in Pass, 325-40. Retrieved from http://ncss.wpengine.netdna-cdn.com/wp-content/themes/ncss/pdf/Procedures/NCSS/Poisson_Regression.pdf

Oliver, L., Ferber, U., Grimski, D., Millar, K., \& Nathanail, P. (2005). The Scale and Nature of European Brownfields. Retrieved from http://www.cabernet.org.uk/resourcefs/417.pdf

Paull, E. (2008). The Environmental and Economic Impacts of Brownfields Redevelopment, Working Draft for Distribution, Northeast-Midwest Institute, July, 1-53. Retrieved from http://www.nemw.org/images/stories/documents/EnvironEconImpactsBFRedev.pdf

Peric, A., \& Furundzic, D. (2014). Institutional Framework of Brownfield Regeneration in Serbia, In Schrenk, M., Popovich, V.V., Zeile, P., \& Elisei, P. (Eds), Proceedings REAL CORP Tagungsband, 21-23 May, Vienna, Austria, 303-307. Retrieved from http://www.corp.at/archive/CORP2014_7.pdf

Porter, E. M. (2007). Understanding Competitiveness and its Causes, Competitiveness Index: Where America Stands, $\begin{array}{lllll}\text { Council on } & \text { Competitiveness, } & 8 . & \text { Retrieved } & \text { from }\end{array}$ http://www.compete.org/publications/all/357-competitiveness-index-where-america-stands

Priručnik za donosioce odluka i profesionalce. (2008). Oživljavanje braunfilda u Srbiji, PALGO centar, In Danilović, K., Stojkov, B., Zeković, S., Gligorijević, Ž., \& Damjanović, D. (Eds), PALGO center, Belgrade, 5-153. Retrieved from http://www.palgo.org/files/knjige/Ozivljavanje\%20braunfilda\%20u\%20Srbiji.pdf

Rashwan, A. N., \& Kamel, M. M. (2011). Using Generalized Poisson Log Linear Regression Models in Analyzing Two-Way Contingency Tables. Applied Mathematical Sciences, 5(5), 213-222. Retrieved from http://www.m-hikari.com/ams/ams-2011/ams-5-8-2011/kamelAMS5-8-2011.pdf 
Reaktiviranje braunfilda u Srbiji (2011). Sistemski pristup ili ad hoc rešenja?, Projekat Institucionalna podrška SKGO, Stalana konferencija gradova i opština, Beograd, 5-33. Retrieved from http://www.skgo.org/upload/files/Analiz_Reaktiviranje_braunfilda_u_Srbiji.pdf

Sala-i-Martin, X., Bilbao-Osorio, B., Di Battista, A., Drzeniek Hanouz, M., Galvan, C., \& Geiger, T. (2014). The Global Competitiveness Index 2014-2015: Accelerating a Robust Recovery to Create Productive Jobs and Support Inclusive Growth. In Schwab, K., \& Sala-I-Martín, X. (Eds), The Global Competitiveness Report 20142015, World Economic Forum, Geneva, Switzerland, 13-20. Retrieved from http://www3.weforum.org/docs/WEF_GlobalCompetitivenessReport_2014-15.pdf

Sala-i-Martin, X., Blanke, J., Drzeniek, M., Geiger, H., Mia, I., \& Paua, F. (2008). The Global Competitiveness Index: Prioritizing the Economic Policy Agenda. In Schwab, K., \& Porter, M. (Eds), The Global Competitiveness Report 2008-2009, World Economic Forum, Geneva, Switzerland, 3-5. Retrieved from http://www3.weforum.org/docs/WEF_GlobalCompetitivenessReport_2008-09.pdf

Serbia Investment and Export Promotion Agency. (2015). Investment incentives, Serbia Investment and Export Promotion Agency - $\quad$ SIEPA. $\quad$ Retrieved from http://siepa.gov.rs/sr/index/finansiranje/finansijska-podrska-za-investitore/

Tang, Y. T. (2011). Investigating Sustainable Land Use: Possible Implications for Brownfield Regeneration Policy. $\mathrm{Ph} . D$. Dissertation, Vol. 1, The University of Nottingham, September, 1-368. Retrieved from http://eprints.nottingham.ac.uk/12380/1/thesis_print_out_for_submission\%2808112011\%29_vol1.pdf

Verbeek, M. (2004). A Guide to Modern Econometrics (2nd ed.) John Wiley \& Sons Ltd.

Vukovic, B. D. (2013). Correlation analysis of indicators of regional competitiveness: The case of the Republic of Serbia. Economic Horizons, 15(3), 201-215. http://dx.doi.org/10.5937/ekonhor1303197v

Yuen, J. (2001). Logistic and Poisson Regression: An Introduction to Generalized Linear Models Uppsala University March 2001, February, 5-44. Retrieved from http://my-krakatau.mykopat.slu.se/ www/logistic/logistic_main.pdf

\section{Appendix}

Table A1. Variable definitions

\begin{tabular}{lc}
\hline \multicolumn{1}{c}{ Variable } & Data sources \\
\hline Browi - brownfield investment (billions \$) & www.naled-serbia.org/search \\
\hline $\begin{array}{l}\text { GDP - gross domestic product at market prices } \\
\text { (billions \$) }\end{array}$ & $\begin{array}{c}\text { The Global Competitiveness Report 2007 - 2013 } \\
\text { www3.weforum.org/docs/WEF }\end{array}$ \\
\hline Qoing - Quality of overall infrastructure & The Global Competitiveness Report 2007 - 2013 \\
& www3.weforum.org/docs/WEF \\
\hline Etii - Effect of taxation on incentives to invest & The Global Competitiveness Report 2007 - 2013 \\
\hline $\begin{array}{l}\text { Aqi - dummy variable Availability and quality } \\
\text { of information }\end{array}$ & $\begin{array}{c}\text { Serbia Investment and Export Promotion Agency (SIEPA) } \\
\text { www.siepa.gov.rs/en/ }\end{array}$ \\
\hline $\begin{array}{l}\text { Leg - dummy variable Legislation } \\
\end{array}$ & $\begin{array}{c}\text { Serbia Investment and Export Promotion Agency (SIEPA) } \\
\text { www.siepa.gov.rs/en/ }\end{array}$ \\
\hline
\end{tabular}

Table A2. Data pertaining to Serbia

\begin{tabular}{cccrccccr}
\hline Country & Year & GDP & BrowI & AQI & QOINF & Leg & \multicolumn{1}{c}{ Etii } \\
\hline SRB & 2007 & 42 & 602.8 & 0 & 2.7 & 1 & 2.6 \\
\hline SRB & 2008 & 50 & 675.1 & 0 & 2.8 & 1 & 2.8 \\
\hline SRB & 2009 & 43 & 656.8 & 0 & 3.0 & 1 & 3.0 \\
\hline SRB & 2010 & 39 & 654.5 & 1 & 3.1 & 1 & 2.9 \\
\hline SRB & 2011 & 45 & 695.8 & 1 & 3.2 & 1 & 2.9 \\
\hline SRB & 2012 & 37 & 691.8 & 1 & 3.4 & 1 & 2.8 \\
\hline SRB & 2013 & 43 & 0 & 1 & 3.3 & 1 & 2.7 \\
\hline
\end{tabular}

Source: Author's 

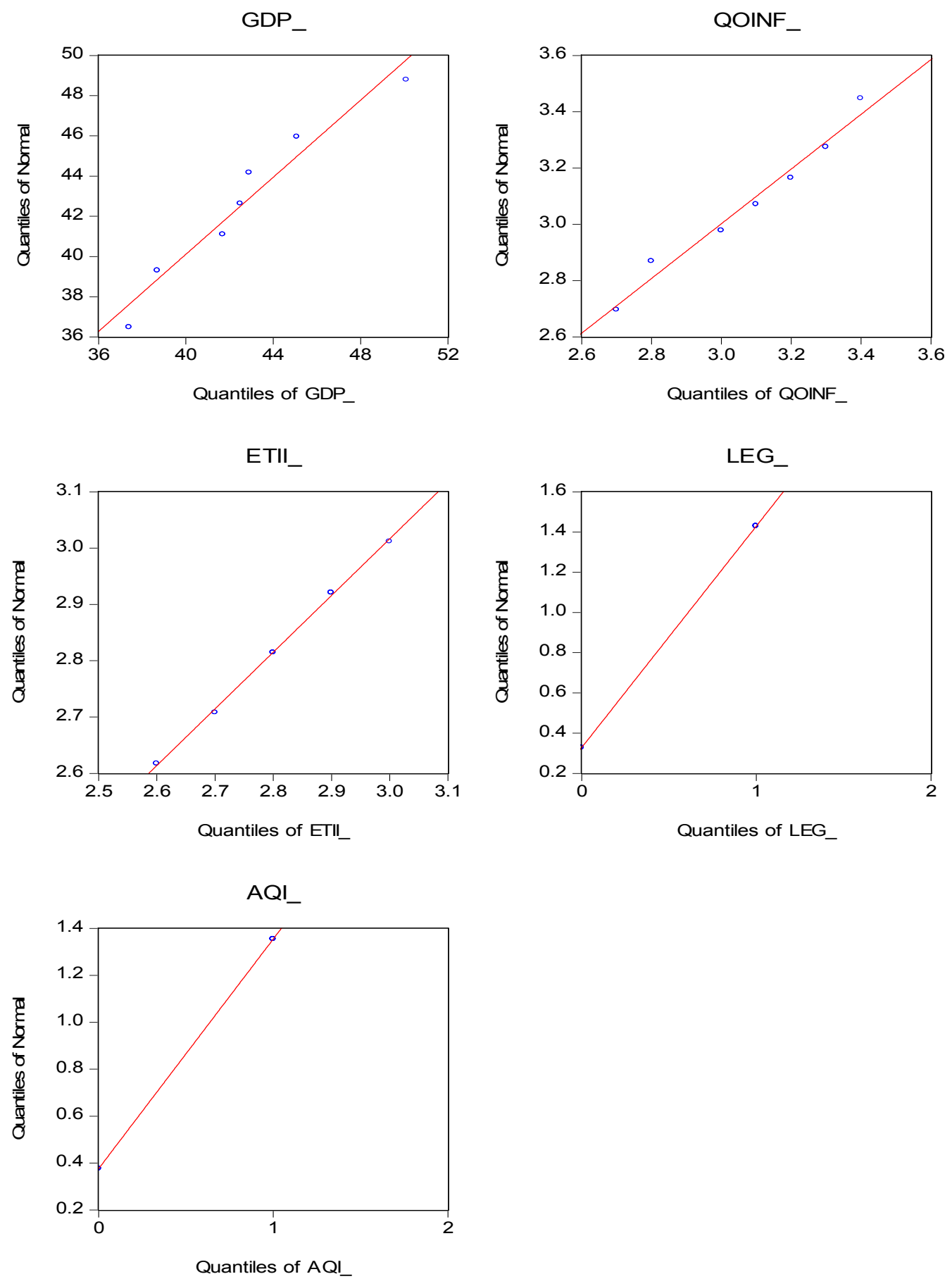

Figure A1. Correlation between independent variables

Source: Author's 


\section{RANK}

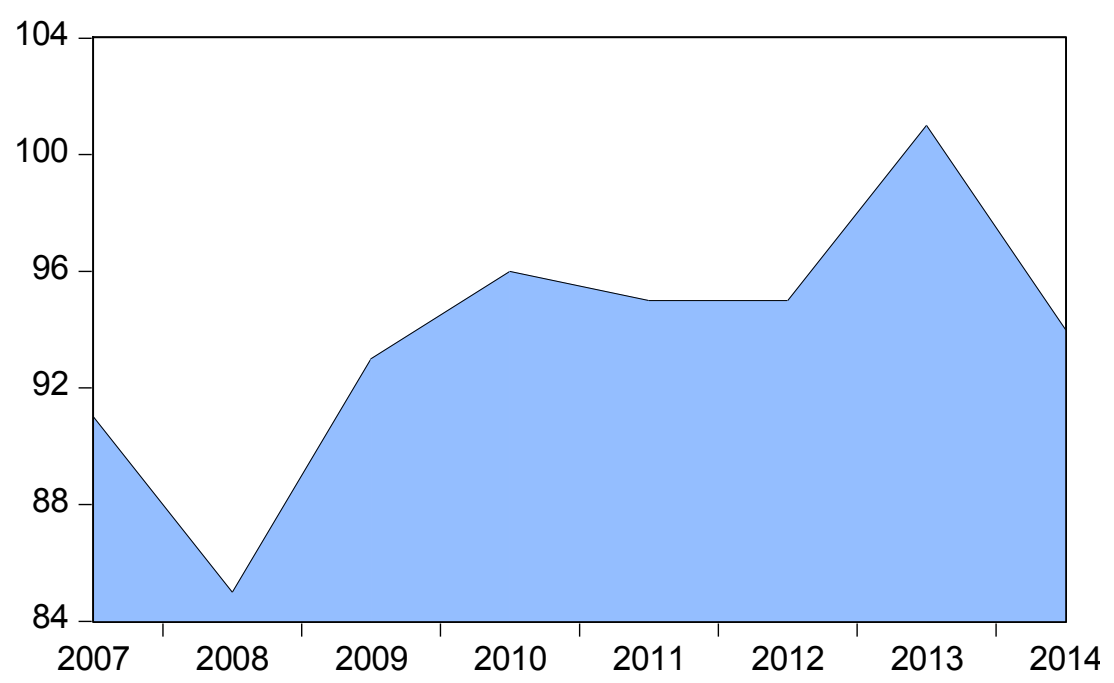

Score (1-7)

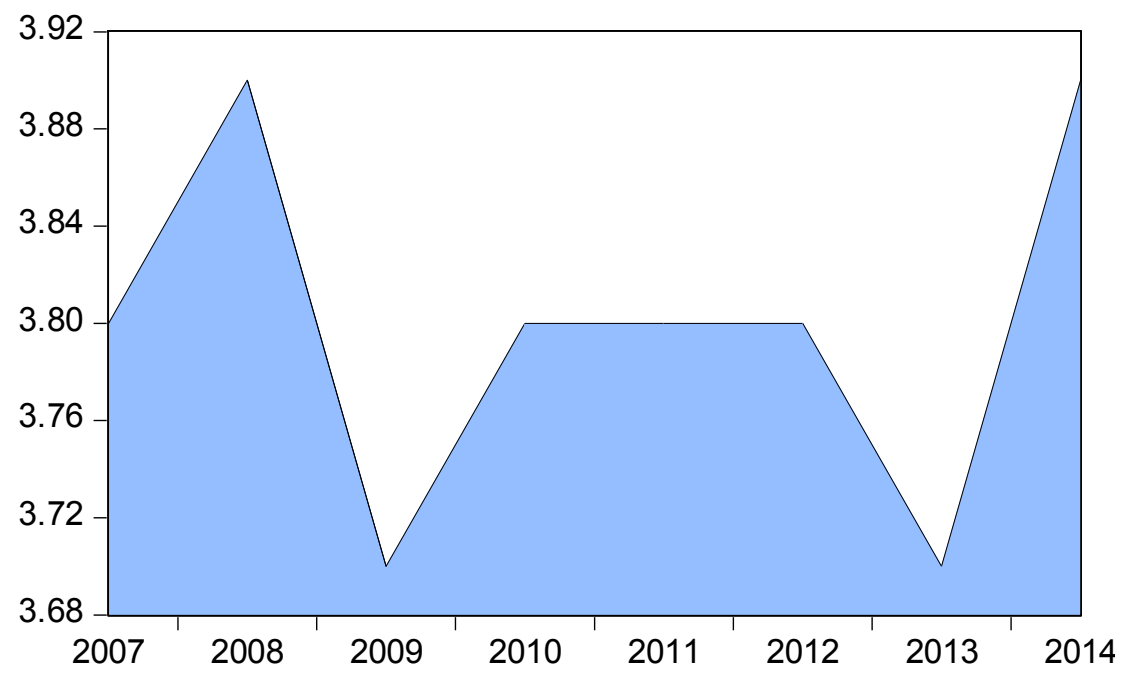

Figure A2. The Global Competitiveness Index 2007-2014: Rank and Score (1-7)

Source: Author's 


\section{RANK}

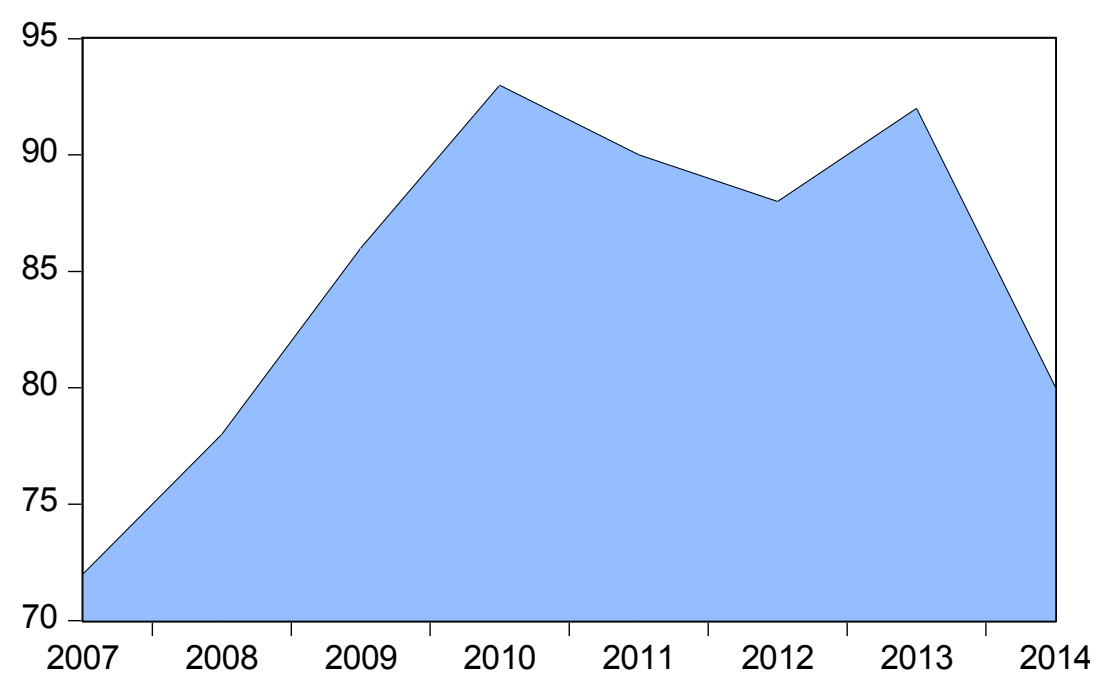

Score (1-7)

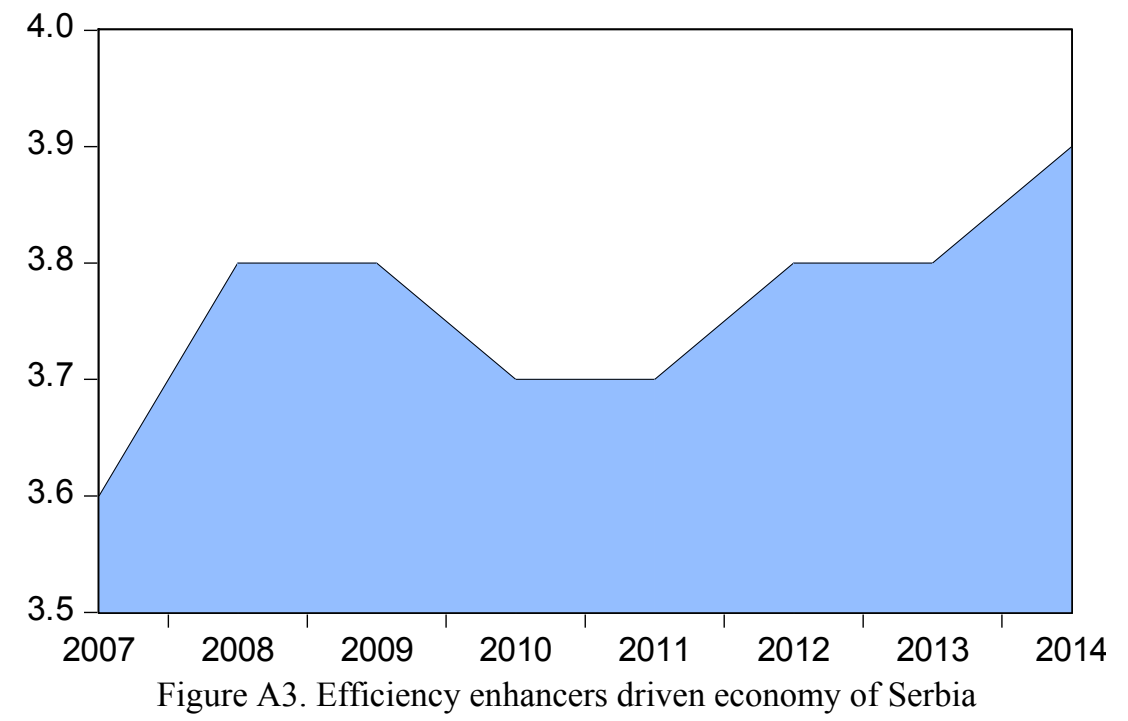

Source: Author's 